\begin{tabular}{c|c|c}
\hline \hline & AQUATIC MICROBIAL ECOLOGY & Aquat Microb Ecol \\
Vol. 31: 249-258, 2003 & Published April 3 \\
\hline \hline
\end{tabular}

\title{
Regulation of periphytic leucine-aminopeptidase activity
}

\author{
Steven N. Francoeur ${ }^{1,2, *}$, Robert G. Wetzel ${ }^{1,3}$ \\ ${ }^{1}$ Department of Biological Sciences, The University of Alabama, Tuscaloosa, Alabama 35487-0206, USA \\ ${ }^{2}$ Present address: Department of Biology, Eastern Michigan University, 316 Mark Jefferson, Ypsilanti, Michigan 48197, USA \\ ${ }^{3}$ Present address: Department of Environmental Sciences and Engineering, The University of North Carolina, Chapel Hill, \\ North Carolina 27599-7431, USA
}

\begin{abstract}
Short-term ( $<24 \mathrm{~h})$ regulation of leucine-aminopeptidase (LAMP) activity in constructed and natural periphyton communities was investigated experimentally. Supply of dissolved inorganic nitrogen ( $\mathrm{NH}_{4}$ and $\mathrm{NO}_{3}$ ) and labile organic carbon (glucose), and active periphytic photosynthesis all affected LAMP activity, and these factors often displayed interactive effects. The variable influence of regulatory factors among experiments and frequent interactive effects indicated that regulation of LAMP activity is a complex, temporally dynamic process. Responses of putatively bacterial LAMP activity to algal photosynthesis suggested that extracellular protease activity is another periphytic process moderated by algal-bacterial coupling. Periphytic LAMP pH optima $(\mathrm{pH}>9.75)$ were much greater than those previously reported for planktonic communities and profundal sediments $(\mathrm{pH} 7.5$ to 8.0), suggesting a mechanism by which photosynthesis could stimulate LAMP activity. In situ LAMP activity of natural wetland periphyton communities displayed diurnal patterns consistent with stimulation of LAMP activity by photosynthetically-induced $\mathrm{pH}$ shifts, but was also directly correlated with the potentially causal factors of dissolved inorganic nitrogen concentration and temperature.
\end{abstract}

KEY WORDS: Periphyton · Biofilm · Extracellular enzymes · Algal-bacterial interaction

Resale or republication not permitted without written consent of the publisher

\section{INTRODUCTION}

Within periphyton communities, autotrophic algae and heterotrophic bacteria can exhibit strong interactions. These interactions are often the rapid $(<24 \mathrm{~h})$ response of bacteria to algal photosynthetic activity. For example, periphytic bacterial and cyanobacterial $\mathrm{N}_{2}$ fixation (Bebout et al. 1987, 1993, Paerl et al. 1996) and bacterial denitrification (Christensen et al. 1990, Nielsen et al. 1990) are quickly inhibited by $\mathrm{O}_{2}$ produced by active photosynthesis. In contrast, nitrification (An \& Joyce 2001, Kemp \& Dodds 2001) and periphytic bacterial productivity (Murray et al. 1986, Neely \& Wetzel 1995, Espeland et al. 2001) can be strongly stimulated by benthic algal photosynthesis. Active photosynthesis may affect the proportion of periphytic bacteria expressing phosphatase (Espeland \& Wetzel 2001b), and the activity of several extracellular enzymes of presumably bacterial origin ( $\alpha$-glucosidase, $\beta$-glucosidase, and $\beta$-xylosidase) can be stimulated by periphytic photosynthetic activity (Espeland et al. 2001). It is probable that the activities of other periphytic extracellular enzymes are influenced by algalbacterial coupling.

Most organic matter in aquatic environments is too large for direct absorption through the cell membrane; thus, extracellular enzymatic hydrolysis is an important process in nutrient cycling and microbial nutrition in aquatic systems. With respect to proteinaceous matter, polypeptides of more than 5 to 7 amino acids ( 650 daltons) are too large for cross-membrane transport (Law 1980, Payne 1980), and therefore require extracellular enzymatic hydrolysis before microbial uptake. Enzymatic hydrolysis is often the rate-limiting step in aquatic microbial nutrient uptake (Chróst 1991, Münster 1991); yet investigations of factors potentially controlling these rates are few, and none deal with periphytic communities. Leucine-aminopeptidase (LAMP) is a common pro- 
tein-degrading extracellular enzyme in aquatic systems (Chróst 1991, 1993). This study examines the potential influence of several factors, including algal-bacterial coupling, on periphytic LAMP activity.

Amino acids frequently serve as sources of both $\mathrm{N}$ and C for aquatic bacteria (Montuelle et al. 1992, Chróst 1993, Rosenstock \& Simon 1993, 2001, Kroer et al. 1994, Keil \& Kirchman 1999). Thus, it is likely that periphytic LAMP activity may be partially regulated by the availability of non-proteinaceous sources of nitrogen and labile organic carbon (LOC). Extracellular protease activity in natural planktonic communities and semi-natural culture systems can be reduced by additions of dissolved inorganic nitrogen (DIN; e.g. $\mathrm{NH}_{4}, \mathrm{NO}_{3}$ ) (Chróst 1991, Francoeur et al. 2001, Sala et al. 2001), but LAMP activity can also be insensitive to DIN additions (Nausch \& Nausch 2000). Previous experimental investigations of natural planktonic and benthic heterotrophic microbial communities have shown that additions of LOC (i.e. glucose, acetate) can decrease extracellular protease activity (Chróst 1991, Boetius \& Lochte 1996a), but LAMP activity is not always affected by such additions (Boetius \& Lochte 1996b, Mallet \& Debroas 2000).

Photosynthesis might be expected to affect LAMP activity through provision of LOC or alteration of $\mathrm{pH}$. Several studies of freshwater habitats indicated that LAMP has a narrow pH optimum, ca. 7.5, with low activity at $\mathrm{pH}<6$ to 7 and rapid decline in activity above pH 8.5 to 9 (Halemejko \& Chróst 1986, Münster 1991, Mallet \& Debroas 1999). Algal photosynthetic activity can cause $\mathrm{pH}$ within periphyton communities to exceed 9 (Jørgensen et al. 1983, Revsbech et al. 1983, Carlton \& Wetzel 1988, Woodruff et al. 1999, Jones et al. 2000, Espeland \& Wetzel 2001a). Thus, photosynthetically-induced $\mathrm{pH}$ shifts might alter LAMP activity.

In aquatic habitats, both photosynthesis and DIN concentration can vary diurnally (e.g. Manny \& Wetzel 1973, Collos et al. 1996, Hessen at al. 1997). If either of these potential regulatory factors exerts a strong influence on LAMP activity, then diurnal patterns in LAMP activity might be expected. Establishing the existence and magnitude of diurnal variability in enzyme activity is an important step in understanding substrate hydrolysis in natural systems.

The specific objectives of this study were to: (1) determine whether photosynthesis could alter periphytic LAMP activity, (2) investigate temporal variability in the independent and interactive effects of potential regulatory factors (DIN, LOC, and photosynthesis) on LAMP activity, (3) assess whether photosyntheticallymediated changes in LAMP activity could result from $\mathrm{pH}$ shifts, and (4) document diel patterns in natural periphytic LAMP activity.

\section{MATERIALS AND METHODS}

Initial experiments using constructed periphyton communities were conducted to investigate the effects of DIN, photosynthesis, and LOC on periphytic LAMP activity under highly controlled conditions. Similar experiments were subsequently conducted with Talladega Wetland Ecosystem (TWE, a 15.1 ha wetland located in the upper Coastal Plain physiographic province of west central Alabama, $32^{\circ} 52^{\prime} \mathrm{N}, 87^{\circ} 26^{\prime} \mathrm{W}$ ) periphyton communities in order to examine regulation of LAMP in natural periphytic assemblages. Constructed periphyton was generated by the method of Francoeur et al. (2001). Briefly, known amounts of stationary-phase cultures of Nitzschia palea (Expts 2 and 3 used Navicula pelliculosa instead of N. palea), Scenedesmus basiliensis, and Anabaena flos-aquae, and a log-phase culture of bacteria from the TWE were mixed together and gently filtered $(<13 \mathrm{kPa})$ onto Millipore GS filters $(0.22 \mu \mathrm{m}$ pore size). The bacterial inoculum was generated by the method of Wetzel et al. (1995), and included Klebsiella pneumoniae, Enterobacter sakazakii, Serratia sp., and an unidentified, gram positive, coccoid bacterium (bacterial identification by fatty acid analysis, Microbial ID, Inc.). Natural periphyton communities were obtained by placing pre-ashed $47 \mathrm{~mm}$ glass-fiber filters (Fisher, $0.7 \mu \mathrm{m}$ nominal pore size) in acrylic/fiberglass supports (Kahn \& Wetzel 1998), submerging the supports in the TWE at a depth of 10 to $15 \mathrm{~cm}$, and allowing a growth period for periphyton to accrue on the filter substrata.

In all experiments with constructed periphyton, known amounts of the cultures used to construct these communities were filtered onto pre-ashed Whatman GF/F filters ( $0.7 \mu \mathrm{m}$ nominal pore size), and assayed for ash-free dry mass (AFDM; dried $24 \mathrm{~h}$ at $110^{\circ} \mathrm{C}$, ashed $3 \mathrm{~h}$ at $500^{\circ} \mathrm{C}$ ) and chl a (Wetzel \& Likens 2000). Samples were also preserved (glutaraldehyde, $2 \%$ final concentration) for direct algal counts (Wetzel \& Likens 2000). AFDM, chl a and algal density of natural periphyton communities were determined from 21.5 or $7 \mathrm{~mm}$ diameter disks of periphyton-covered filter substrata. Preliminary experiments with constructed and natural periphyton were performed to ensure that enzyme assays were conducted under saturating conditions.

Experimental design is summarized in Table 1. In all experiments, single $7 \mathrm{~mm}$ diameter disks of periphyton were placed individually into vials containing modified Moss medium (Moss 1972). The modified Moss medium used in experiments did not contain any source of organic $\mathrm{N}$ or organic C. DIN was manipulated by either including $(+\mathrm{N}$ medium,

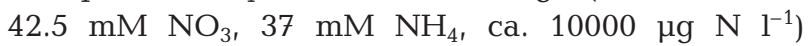
or excluding ( $-\mathrm{N}$ medium, $0 \mu \mathrm{g} \mathrm{N} \mathrm{l}^{-1}$ ) $\mathrm{NH}_{4} \mathrm{Cl}$ and 
Table 1. Experimental design for the individual experiments in this study. DIN = dissolved inorganic nitrogen, LOC = labile organic carbon, Ps = photosynthesis. Growth period $=$ days that substrata were exposed for microbial colonization in the wetland prior to natural periphyton communities being used for experiments

\begin{tabular}{|c|c|c|c|c|}
\hline \multicolumn{5}{|c|}{ Constructed periphyton } \\
\hline Expt: & 1 & 2 & \multicolumn{2}{|l|}{$3 a / 3 b$} \\
\hline Factor & DIN, Ps & DIN, LOC, Ps & $\mathrm{pH}$ & \\
\hline $\mathrm{n}$ & 3 & 4 & $4 / 2$ & \\
\hline \multicolumn{5}{|c|}{ Natural periphyton } \\
\hline Expt: & 4 & 5 & 6 & $7 a / 7 b$ \\
\hline Growth period (d & 21 & 20 & 29 & $29 / 20$ \\
\hline Date & $5 \mathrm{Nov}$ & $7 \mathrm{Dec}$ & $18 \mathrm{Feb}$ & 18 Feb/28 Feb \\
\hline Factor & DIN, LOC, Ps & DIN, LOC, Ps & DIN, LOC, Ps & $\mathrm{pH}$ \\
\hline $\mathrm{n}$ & 6 & 6 & 6 & $6 / 2$ \\
\hline
\end{tabular}

96-well tissue culture plate. 7-amino-4methylcoumarin (AMC) fluorescence was measured with a Millipore Cytofluor 23 plate reading fluorometer (360/40 ex [excitation wavelengths], 460/40 em [emission wavelengths]). A standard curve of fluorescence intensity vs. AMC concentration was used to convert fluorescence into AMC concentration. Enzyme activity was expressed as velocity (total amount of AMC produced per hour of incubation time). For Expts 3 and 7, separate standard curves were made at each $\mathrm{pH}$. Experimental conditions (DIN, LOC, photosynthesis, and $\mathrm{pH}$ ) were maintained throughout all LAMC incubation periods. Data from individual $\mathrm{Ca}\left(\mathrm{NO}_{3}\right)_{2}$ from the modified Moss medium. LOC was manipulated by addition of glucose (Expt 4: $0.55 \mathrm{mM}$ glucose; Expts 3, 5 and 6: $1.1 \mathrm{mM}$ glucose). Photosynthesis was controlled by incubating vials in either complete darkness or in light (35 to $55 \mu \mathrm{mol} \mathrm{m} \mathrm{m}^{-2} \mathrm{~s}^{-1}$ photosynthetically active radiation). Media $\mathrm{pH}$ in all experiments was 7, except for Expts 3 and 7. In Expts 3a and $7 \mathrm{a}, \mathrm{pH}$ was maintained at either 7 or 9 by the addition of $1 \mathrm{mM}$ Bis-Tris propane buffer to modified Moss medium. During these experiments, some recrystallization of (presumably) Bis-Tris buffer occurred in the stock jars, but was never observed in the experimental vials. For Expts $3 \mathrm{~b}$ and $7 \mathrm{~b}, \mathrm{pH}$ gradients were established by adjusting the $\mathrm{pH}$ of modified Moss medium with $\mathrm{HCl}$ and $\mathrm{NaOH}$. All $\mathrm{pH}$ experiments were conducted in darkness.

Except for Expts $3 \mathrm{~b}$ and $7 \mathrm{~b}$, the experimental conditions (DIN, LOC, photosynthesis and $\mathrm{pH}$ ) were maintained for $20 \mathrm{~h}$ at $30^{\circ} \mathrm{C}$ (constructed periphyton) or $21 \mathrm{~h}$ at $20^{\circ} \mathrm{C}$ (natural periphyton) before enzyme assay. Thus, the enzymatic responses measured include both the effect of the experimental treatment on the activity of enzyme molecules and the synthesis of new LAMP under experimental conditions. For Expts $3 \mathrm{~b}\left(30^{\circ} \mathrm{C}\right)$ and $7 \mathrm{~b}\left(20^{\circ} \mathrm{C}\right)$, enzymatic assay began immediately after the imposition of the $\mathrm{pH}$ gradient, in order to better measure the direct effects of $\mathrm{pH}$ on the activity of enzyme molecules, and minimize the effects of LAMP production.

To quantify LAMP activity, the fluorogenic substrate leucine 7-amido-4-methylcoumarin (LAMC, dissolved in appropriate medium) was added to each vial (600 $\mu \mathrm{M}$ final concentration). After incubation (3 $\mathrm{h}$ for constructed periphyton, $1 \mathrm{~h}$ for natural periphyton), $150 \mu \mathrm{l}$ of the overlying media from each vial was added to $50 \mu \mathrm{l}$ of potassium carbonate-potassium boratepotassium hydroxide buffer $(\mathrm{pH} 10)$ in the wells of a experiments were analyzed using ANOVA; data were $\log (x+1)$ transformed when necessary (Zar 1984).

To measure diurnal changes in LAMP activity, natural periphyton communities were grown on filters in the TWE (6 to $7 \mathrm{~d}$ ) as previously described. At intervals along 2 day/night cycles (June 15 to 16), $7 \mathrm{~mm}$ diameter cores were cut and placed into vials with $600 \mu \mathrm{M}$ LAMC (freshly $0.22 \mu \mathrm{m}$ filtered TWE water as diluent). Vials were incubated in situ (depth $\sim 1.5 \mathrm{~cm}$ ) for $1 \mathrm{~h}$, then the overlying water was removed and placed in ice for transport to the lab. Blanks (600 $\mu \mathrm{M}$ LAMC without periphyton) were used to correct for fluorescence caused by nonenzymatic processes and enzymes dissolved in the filtered TWE water. Immediately upon return to the laboratory (1 h), AMC fluorescence was measured as previously described. A standard curve of AMC fluorescence in filtered TWE water was used to convert measured AMC fluorescence to AMC concentration. At each sampling visit, water temperature was measured, and field-filtered TWE water $(0.45 \mu \mathrm{m})$ was placed into acid-washed bottles, returned to the laboratory on ice, and frozen for storage prior to $\mathrm{NH}_{4}$, $\mathrm{NO}_{3}, \mathrm{NO}_{2}$ and SRP analysis (automated ion analysis, Lachat Instruments). Spearman's rank correlation was used to examine the relationships of LAMP activity to water temperature and dissolved nutrient concentrations.

Low-biomass periphyton communities were used throughout this study. Experimental periphyton communities were generally of less or equal biomass than the communities used to determine saturating conditions for LAMP activity assays (Table 2).

\section{RESULTS}


Despite somewhat variable in situ growth periods, the biomass of natural periphyton communities was similar among experiments. Natural algal communities were dominated by unicellular and colonial chlorophytes (e.g. Oocystis) and euglenophytes (Trachelomonas), with occasional pennate diatoms (e.g. Eunotia, Synedra), filamentous chlorophytes (Oedogonium, Mougeotia), and chrysophytes (Ophiocytium). Cyanobacteria were rare, and $\mathrm{N}_{2}$-fixing taxa were never observed. Scenedesmus basiliensis and Anabaena flos-aquae were the dominant algae in constructed communities; diatoms were less common.

\section{Effects of DIN and photosynthesis - constructed periphyton}

Expt 1

The lack of DIN increased $(p<0.001)$ and photosynthesis decreased $(p=0.001)$ area-specific LAMP activity in constructed periphyton communities (Fig. 1). DIN exclusion had a somewhat larger effect on LAMP activity than did photosynthesis; elimination of DIN supply caused a doubling of LAMP activity, whereas complete inhibition of photosynthesis resulted in a $33 \%$ increase in LAMP activity. A significant DIN $\times$ photosynthesis interaction $(\mathrm{p}=$ 0.036) indicated that LAMP activity in $\mathrm{N}$-deficient communities showed greater sensitivity to photosynthesis.

\section{Effects of DIN, photosynthesis and LOC - constructed periphyton}

Expt 2

Glucose supply ( $\mathrm{p}<0.001$ ) strongly regulated area-specific LAMP activity, but DIN availability $(p<0.002)$ and photosynthesis $(p=0.01)$ also had significant effects (Fig. 2). Large differences in the response of LAMP activity to photosynthesis in DIN-free treatments caused strong DIN $\times$ photosynthesis $(p<0.001)$ and glucose $\times$ photosynthesis $(\mathrm{p}<0.001)$ interactions. In DIN-containing media, LAMP activity was greatly reduced by glucose additions, regardless of photosynthesis $67 \%$ reduction in light, $75 \%$ reduction in dark). In communities without a DIN source, glucose addition did not affect LAMP activity in light-grown communities (13\% reduction, not statistically significant) but greatly reduced ( $75 \%$ reduction) LAMP activity in dark-grown communities (DIN $\times$ glucose $\times$ photosynthesis interaction, $\mathrm{p}<0.001$ )

\section{Effect of $\mathrm{pH}$ - constructed periphyton}

Expt 3

In Bis-Tris buffered media, LAMP activity was approximately 2-fold greater at $\mathrm{pH} 9$ than at $\mathrm{pH} 7$ ( $\mathrm{p}<$ 0.001; Fig. 3A). LAMP activity increased monotonically with increasing $\mathrm{pH}$; LAMP activity was 3.8-fold greater at pH 9.9 than at pH 5 (Fig. 3B).

Table 2. Biomass characteristics of constructed and natural periphyton communities used in experiments. Values are means, with $\mathrm{SD}$ in parentheses. $\mathrm{nd}=$ not determined, $\mathrm{AFDM}=$ ash free dry mass, LAMP = leucine-aminopeptidase

\begin{tabular}{|c|c|c|c|}
\hline Expt & $\operatorname{AFDM}\left(\mathrm{mg} \mathrm{cm}^{-2}\right)$ & $\mathrm{Chl}\left(\mathrm{mg} \mathrm{cm}^{-2}\right)$ & Algal density (cells $\mathrm{cm}^{-2}$ ) \\
\hline \multicolumn{4}{|l|}{ Constructed periphyton } \\
\hline Preliminary saturation experiment & $0.38(0.04)$ & $1.52(0.22)$ & $1.5 \cdot 10^{6}\left(2.8 \times 10^{5}\right)$ \\
\hline Expt 1 & $0.38(0.01)$ & $1.18(0.43)$ & $1.6 \cdot 10^{6}\left(1.1 \times 10^{5}\right)$ \\
\hline Expt 2 & $0.16(0.02)$ & $0.48(0.05)$ & $1.5 \cdot 10^{6}\left(9.8 \times 10^{4}\right)$ \\
\hline \multicolumn{4}{|l|}{ Expt 3} \\
\hline 3a Manipulation experiment & $0.16(0.02)$ & $0.48(0.05)$ & $1.5 \cdot 10^{6}\left(9.8 \times 10^{4}\right.$ \\
\hline 3b Optima curve & $0.50(0.01)$ & $1.20(0.14)$ & $1.7 \cdot 10^{6}\left(2.4 \times 10^{5}\right)$ \\
\hline \multicolumn{4}{|l|}{ Natural periphyton } \\
\hline Preliminary saturation experiment & $0.13(0.02)$ & $0.17(0.06)$ & $3.1 \cdot 10^{4}\left(7.0 \times 10^{3}\right)$ \\
\hline Expt 4 & $0.13(0.02)$ & $0.17(0.06)$ & $3.1 \cdot 10^{4}\left(7.0 \times 10^{3}\right)$ \\
\hline Expt 5 & $0.09(0.01)$ & $0.09(0.02)$ & nd \\
\hline Expt 6 & $0.11(0.02)$ & $0.17(0.05)$ & $1.7 \cdot 10^{4}\left(4.0 \times 10^{3}\right)$ \\
\hline \multicolumn{4}{|l|}{ Expt 7} \\
\hline 7a Manipulation experiment & $0.11(0.02)$ & $0.17(0.05)$ & $1.7 \cdot 10^{4}\left(4.0 \times 10^{3}\right)$ \\
\hline 7b Optima curve & $0.09(0.01)$ & $0.14(0.02)$ & $1.7 \cdot 10^{4}\left(2.9 \times 10^{3}\right)$ \\
\hline \multicolumn{4}{|l|}{ Diurnal patterns in LAMP activity } \\
\hline Day 1 & $0.14(0.02)$ & $0.18(0.05)$ & nd \\
\hline Night 1 & $0.10(0.01)$ & $0.23(0.06)$ & nd \\
\hline
\end{tabular}




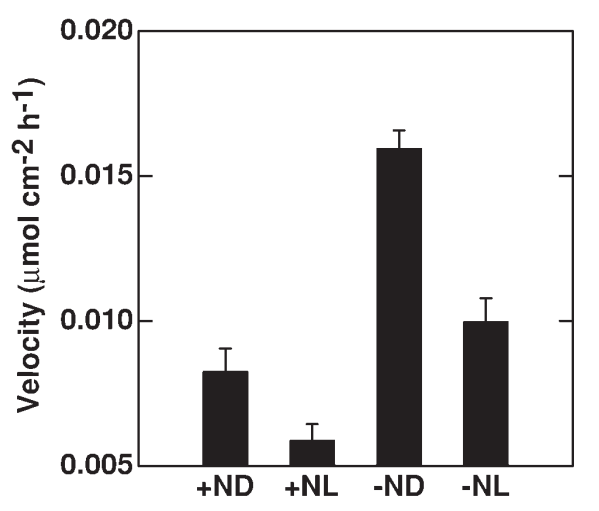

Fig. 1. Effect of dissolved inorganic nitrogen (DIN) supply and photosynthesis on leucine-aminopeptidase (LAMP) activity in constructed periphyton communities. $+\mathrm{N}=$ incubated with DIN,$-\mathrm{N}=$ incubated without DIN, $\mathrm{L}=$ incubated in light, $\mathrm{D}=$ incubated in dark. Bars are $\pm 1 \mathrm{SE}$

\section{Effects of DIN, photosynthesis and LOC — natural periphyton}

\section{Expt 4}

Exclusion of DIN caused generally large (5 to $65 \%$, within each combination of glucose and photosynthesis) increases in area-specific LAMP activity ( $p<0.001$, Fig. 4A). Neither glucose ( $p=0.31$ ) nor photosynthesis $(\mathrm{p}=0.57)$ had any significant independent effect, but there were significant interactive effects of DIN supply with glucose $(p=0.024)$ and photosynthesis $(p=0.032)$.

\section{Expt 5}

There was a highly significant interactive effect of DIN supply and glucose $(\mathrm{p}=0.003)$. LAMP activity was $34 \%$ greater in treatments amended with both DIN and glucose than in all other treatments (Fig. 4B). Significant direct effects of DIN ( $p=0.043)$ and glucose $(p=0.007)$ were the result of the large response of dual-enriched treatments.

\section{Expt 6}

Photosynthesis caused large (23 to $41 \%$, within each combination of DIN and glucose), highly significant $(p<0.001)$ increases in LAMP activity (Fig. 4C). In comparison, glucose addition caused marginally significant ( $p=0.052$ ), small (2 to $18 \%$, within each combination of DIN and photosynthesis) reductions in area-specific LAMP activity. Communities supplied with DIN displayed significantly increased $(p<0.001)$ LAMP activity.

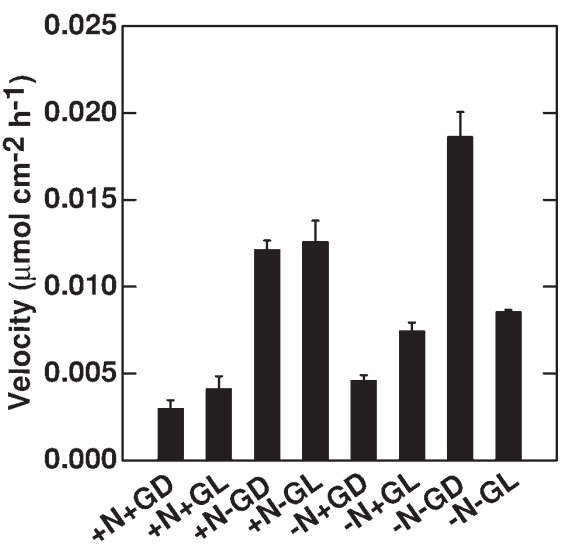

Fig. 2. Effect of dissolved inorganic nitrogen (DIN) supply, photosynthesis, and labile organic carbon (LOC) on leucineaminopeptidase (LAMP) activity in constructed periphyton. $+\mathrm{N}=$ incubated with DIN,$-\mathrm{N}=$ incubated without DIN,$+\mathrm{G}=$ incubated with glucose, $-\mathrm{G}=$ incubated without glucose, $\mathrm{L}=$ incubated in light, $\mathrm{D}=$ incubated in dark. Bars are $\pm 1 \mathrm{SE}$

\section{Effect of $\mathrm{pH}$ - natural periphyton}

\section{Expt 7}

In Bis-Tris buffered media, area-specific LAMP activity was over 1.5-fold greater at $\mathrm{pH} 9$ than at $\mathrm{pH} 7$ ( $p<0.02$; Fig. 5A). LAMP activity increased monotonically with increasing $\mathrm{pH}$, and was 2.75 -fold greater at pH 9.75 than at pH 5.93 (Fig. 5B).

\section{Diurnal patterns in LAMP activity}

LAMP activity varied with respect to the day/night cycle (Fig. 6A). Area-specific LAMP activity during daylight sampling was $\sim 2$-fold greater $(\mathrm{p}<0.001$, $t$-test) than LAMP activity at night. Water temperature and DIN concentrations also varied diurnally (Fig. $6 \mathrm{~B}, \mathrm{C})$ and were similar to those observed during other investigations at the TWE (Johnson 1995, Stanley \& Ward 1997). LAMP activity was positively correlated with water temperature $(\mathrm{r}=0.77, \mathrm{p}<0.001)$ and $\mathrm{NO}_{3}$ $(\mathrm{r}=0.57, \mathrm{p}<0.001)$, and negatively correlated with $\mathrm{NH}_{4}(\mathrm{r}=-0.65, \mathrm{p}<0.001) . \mathrm{NO}_{2}$ concentrations were negligible. The preponderance of $\mathrm{NH}_{4}$ relative to $\mathrm{NO}_{3}$ and $\mathrm{NO}_{2}$ resulted in an overall negative correlation of LAMP activity to DIN ( $\mathrm{r}=-0.39, \mathrm{p}<0.01)$. LAMP activity and SRP were uncorrelated $(\mathrm{r}=0.16, \mathrm{p}>0.2)$.

\section{DISCUSSION}

The origin of LAMP in these experiments was not directly assessed, but it is most likely to have been bac- 

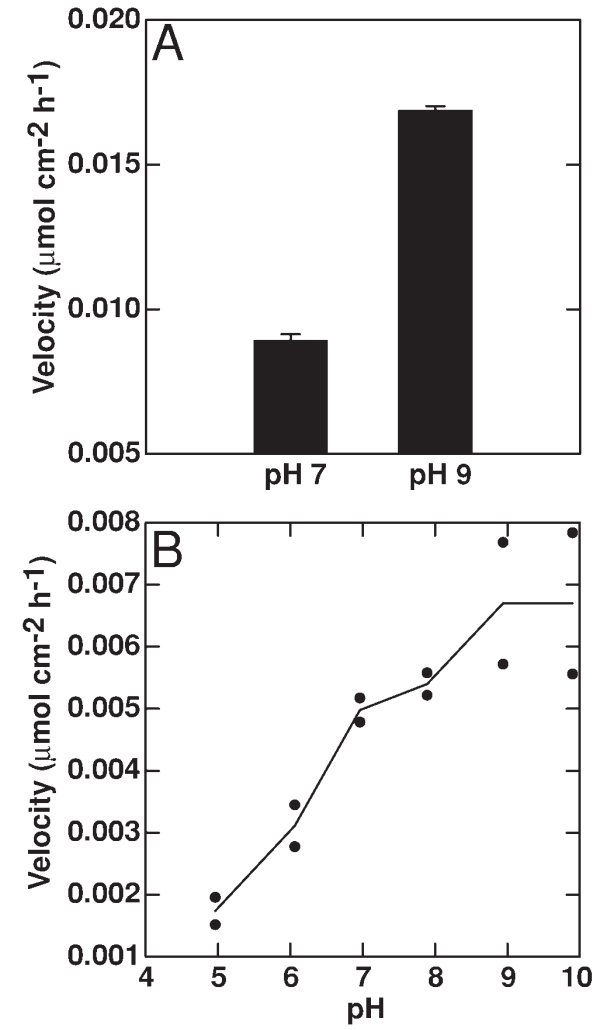

Fig. 3. Effect of pH on leucine-aminopeptidase (LAMP) activity in constructed periphyton. (A) Experimental manipulation of $\mathrm{pH}$ with Bis-Tris buffer. Bars are \pm 1 SE. (B) LAMP activity at various $\mathrm{pH}$ values

terial. Although some extracellular proteases are of algal origin (Hoppe 1986, Martinez \& Azam 1993, Matsuda et al. 1995), most extracellular proteolytic activity in aquatic environments is associated with bacterial cells, with variable amounts of activity in the dissolved form (Hoppe 1983, Rego et al. 1985, Münster 1992, Chróst \& Rai 1993, Unanue et al. 1993, Hoppe et al. 1998, Richardot et al. 1999). Thus, the response of LAMP activity to periphytic photosynthesis provides another example of algal-bacterial coupling within periphyton communities.

To our knowledge, the present study is the first examination of the effect of photosynthesis on extracellular protease activity. Other studies have compared extracellular enzyme activities between heterotrophic, dark-grown biofilms, and auto/heterotrophic lightgrown periphyton communities (Jones \& Lock 1993, Sinsabaugh \& Linkins 1988, Romani \& Sabater 2000), and Espeland et al. (2001) recently found that active photosynthesis stimulated periphytic glucosidase and xylosidase activities. Several experiments in this study (Expts 1, 2 and 6) demonstrated rapid coupling of periphytic photosynthetic activity and periphytic LAMP activity. The heterogeneous responses of LAMP activ-
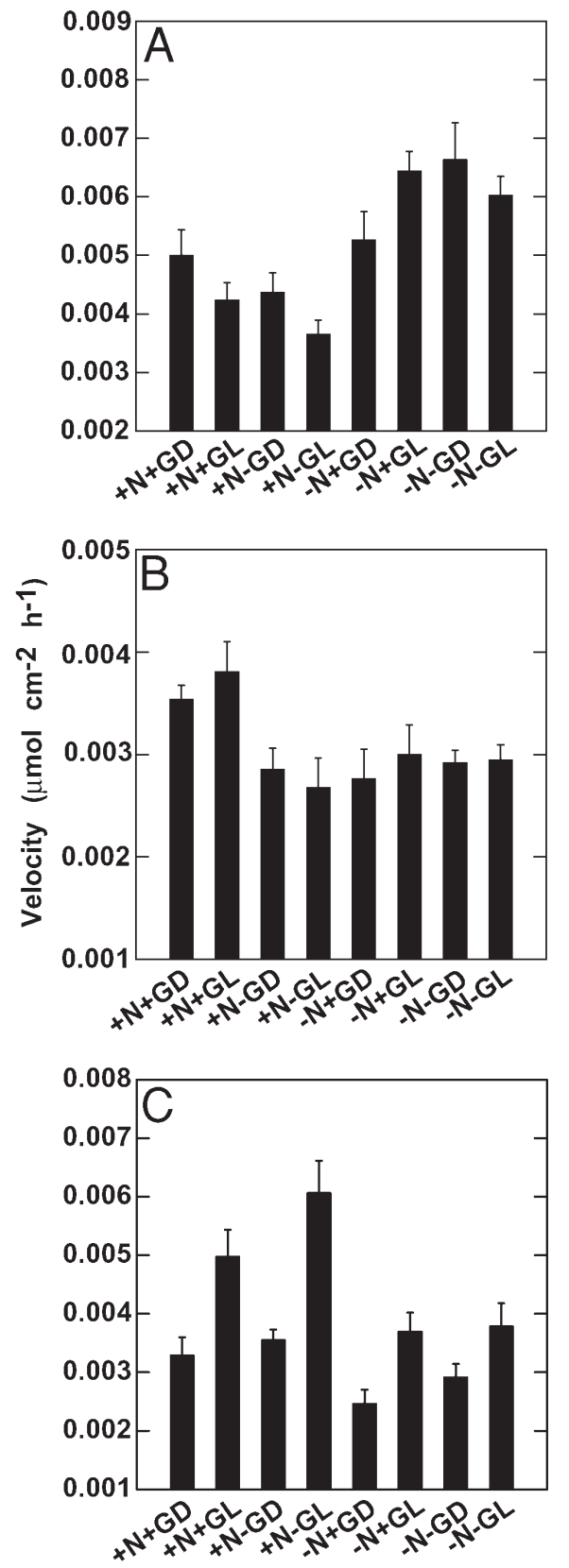

Fig. 4. Effect of dissolved inorganic nitrogen (DIN) supply, photosynthesis, and labile organic carbon (LOC) on leucineaminopeptidase (LAMP) activity in natural periphyton. (A) Expt 4 (5 November), (B) Expt 5 (7 December), (C) Expt 6 (18 February). $+\mathrm{N}=$ incubated with $\mathrm{DIN},-\mathrm{N}=$ incubated without DIN, $+\mathrm{G}=$ incubated with glucose, $-\mathrm{G}=$ incubated without glucose, $\mathrm{L}=$ incubated in light, $\mathrm{D}=$ incubated in dark. Bars are \pm 1 SE

ity to periphytic photosynthesis observed among different experiments of this study indicate that the influence of photosynthesis varies temporally, and suggests that the mechanisms linking LAMP activity to photosynthesis differed among the experiments (e.g. possi- 

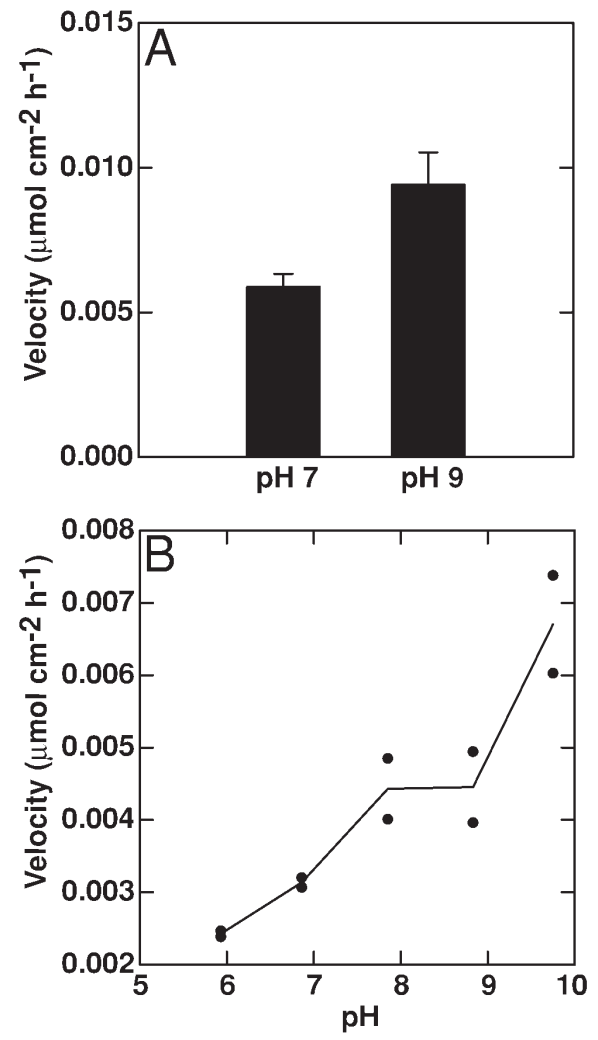

Fig. 5. Effect of pH on leucine-aminopeptidase (LAMP) activity in natural periphyton. (A) Experimental manipulation of $\mathrm{pH}$ with Bis-Tris buffer. Bars are \pm 1 SE. (B) LAMP activity at various $\mathrm{pH}$ values

ble inhibition via supply of LOC vs. stimulation by increased $\mathrm{pH}$ ).

Proteins and amino acids can serve as both nitrogen and carbon/energy sources for aquatic bacteria (e.g. Montuelle et al. 1992, Chróst 1993, Rosenstock \& Simon 1993, 2001, Kroer et al. 1994, Keil \& Kirchman 1999). Thus, it has been suggested that increasing extracellular protease activity might be a carbon/ energy acquiring strategy (Chróst 1993, Boetius \& Lochte 1996a, Sinsabaugh et al. 1997). In constructed periphyton communities, addition of glucose greatly decreased LAMP activity, whereas addition of glucose had little effect on natural periphyton. This suggests that constructed communities were less $\mathrm{C}$ replete than natural periphyton, and may have been the result of microbes in natural periphyton having access to alternative LOC sources, such as intracellular reserves or abundant extracellular polysaccharides. Overall, these results are consistent with studies of plankton (Chróst 1991) and deep-sea sediments (Boetius \& Lochte 1996a) which found that LOC additions (glucose, acetate) reduced planktonic LAMP activity, although in other studies provision of LOC did not always reduce LAMP activity (Boetius \& Lochte 1996b, Mallet

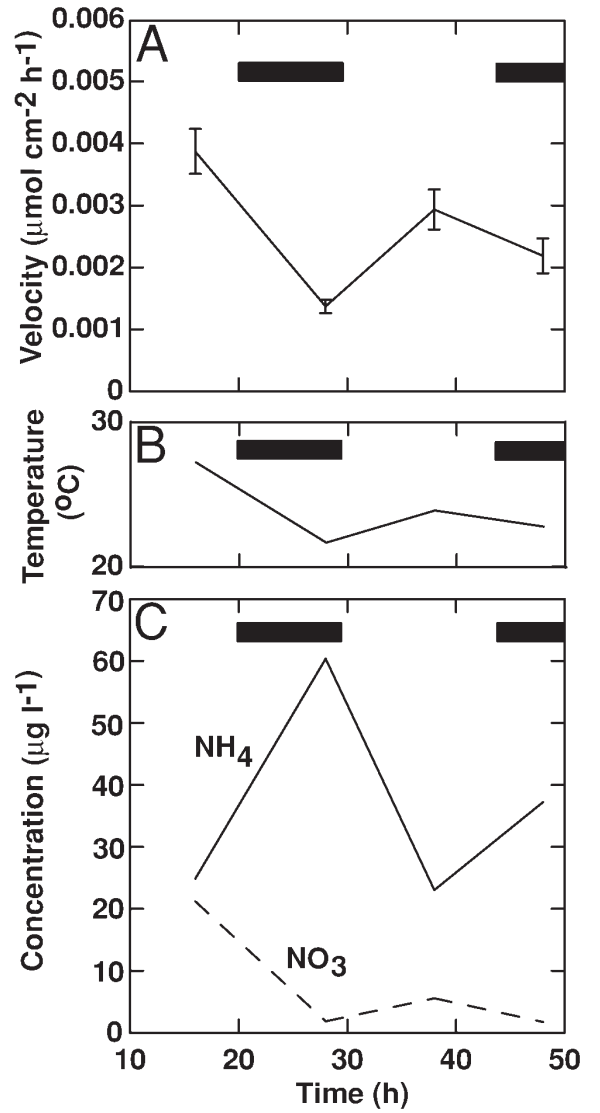

Fig. 6. Diurnal patterns of (A) leucine-aminopeptidase (LAMP) activity in natural periphyton communities, (B) water temperature, and $(\mathrm{C})$ nitrate and ammonium concentrations in Talladega Wetland Ecosystem (TWE) water. Horizontal dark bars indicate darkness; vertical bars are $\pm 1 \mathrm{SE}$

\& Debroas 2000). Taken together, these results indicate that extracellular protease activity can be partially regulated by the carbon/energy supply to microbes.

LAMP activity was also strongly influenced by $\mathrm{pH}$. Adjusting $\mathrm{pH}$ of buffered media from 7 to 9 greatly increased LAMP activity in both constructed and natural periphyton. The natural periphyton communities that displayed stimulation of LAMP activity by experimentally increased pH (Expt 7a) were the same communities that displayed significantly increased LAMP activity in response to active photosynthesis (Expt 6), further strengthening the probability that photosynthetically mediated $\mathrm{pH}$ shifts stimulated periphytic LAMP activity.

LAMP $\mathrm{pH}$ optima have been determined for freshwater planktonic communities (Halemejko \& Chróst 1986, Münster 1991), and profundal lake sediments (Mallet \& Debroas 1999). In these previous studies, optimal $\mathrm{pH}$ was $\sim 7.5$ to 8.0 , with low activity at $\mathrm{pH}<6$ to 7 and sharp declines in LAMP activity at $\mathrm{pH}>8.5$ to 9. In contrast, the LAMP $\mathrm{pH}$ optimum of natural peri- 
phyton communities in this study was at least 9.75. These results suggest that periphytic extracellular LAMP activity may be adapted to the more alkaline $\mathrm{pH}$ characteristic of actively photosynthesizing periphyton communities, and that photosynthetically induced, diurnal shifts in $\mathrm{pH}$ could cause diurnal patterns in the hydrolysis of proteinaceous compounds. The high $\mathrm{pH}$ optima of periphytic LAMP is similar to that observed for intertidal marine mudflat sediments ( 9.0; Mayer 1989). Shallow, well-lit habitats such as surficial mudflat sediments may also experience $\mathrm{pH}$ shifts because of microalgal photosynthesis. A similar relationship between $\mathrm{pH}$ and LAMP activity may also exist in lotic periphyton, as epilithic LAMP activity was positively correlated with $\mathrm{pH}$ (range 5.5 to 8.5 ) in several British streams (Ainsworth \& Goulder 2000a,b).

Some experiments (Expts 1,2 and 4) using both constructed periphyton and natural periphyton communities revealed that short-term $(\sim 21 \mathrm{~h})$ incubation in DINfree media could cause significant increases in extracellular LAMP activity, relative to communities incubated in DIN-rich media. Such responses (probably caused by rapid synthesis of proteases in response to nitrogen deprivation) have also been noted for bacterial cultures (Stepanauskas et al. 1999), lentic bacterioplankton (Chróst 1991), and simulated periphyton communities (Francoeur et al. 2001). Addition of DIN can also prevent increased LAMP activity in marine plankton (Sala et al. 2001). The results of these experiments support the hypothesis that nitrogen availability in the environment can regulate extracellular protease activity.

However, area-specific periphytic extracellular LAMP activity did not always increase when communities were incubated in nitrogen-free media. In Expts 6 and 7, LAMP activity was significantly greater in DIN-rich communities (Fig 4). In these experiments, it may be the case that DIN addition increased the abundance of enzyme-producing bacteria, thereby increasing overall area-specific LAMP activity. Similar responses are known to occur in fertilized planktonic communities (Chróst \& Rai 1993).

Several experiments (Expts 1, 2, 4 and 5) demonstrated that the response of LAMP activity to manipulations of a given factor (e.g. LOC) was conditioned on the status of other factors (e.g. DIN). The existence of strong interactive effects among regulatory factors indicates that the regulation of LAMC activity in periphyton communities is a complex process, with numerous factors simultaneously exerting influence.

Regulation of periphytic LAMP activity in the TWE was dynamic on the timescale of weeks to months. Expts 4, 5 and 6 (conducted 5 November, 7 December, and 18 February) imposed almost identical treatments on natural periphyton communities of similar biomass and algal community composition from a single habitat under controlled laboratory conditions, yet obtained strikingly different results. The reason for this amongexperiment variation is unknown, and many possibilities exist (e.g. differences in intracellular nitrogen or carbon reserves, bacterial abundance and community composition). Whatever the underlying cause(s), it is clear that the dynamic nature of LAMP regulation makes the extrapolation of the results of any single experiment to longer timescale an undertaking fraught with uncertainty. In short, a single experiment can indicate that a particular regulatory factor is influential, but multiple experiments in a temporal sequence are required to document the duration of that factor's influence on periphytic LAMP activity.

Field measurements of LAMP activity in natural periphyton confirmed the existence of diurnal patterns in LAMP activity; LAMC hydrolysis was greater during daylight hours. The observed stimulation of periphytic LAMP activity by short-term $(\sim 21 \mathrm{~h})$ manipulations of photosynthetic activity (Expt 6) suggested that photosynthesis caused these diurnal patterns. However, this is not the only plausible explanation. Temperature and DIN supply can also affect LAMP activity, and observed fluctuations in water temperature and DIN concentration were consistent with hypotheses postulating that some or all of the diurnal pattern in periphytic LAMP activity resulted from diurnal fluctuations in these factors. Diurnal patterns in LAMP activity have been previously observed in lotic plankton communities; these planktonic patterns were unrelated to photoperiod, but were correlated with protein concentrations (Halemejko \& Chróst 1986). Whatever the cause(s), such temporal patterns in LAMP activity imply that there are diurnal variations in the rates of natural substrate hydrolysis and the supply of bioavailable products. It is also probable that periphytic bacterial productivity and the activities of other extracellular enzymes will show similar diurnal patterns.

Area-specific enzyme activity of periphyton communities is analogous to volume-specific enzyme activity of plankton, and subject to the similar interpretations and limitations. Area-specific enzyme activity may be altered in 3 ways: (1) change in the abundance/ biomass of enzyme-producing organisms, (2) change in the amount of enzyme produced per organism, or (3) change in the activity of individual enzyme molecules. Without information on the specific abundance and biomass of enzyme-producing organisms, it is impossible to distinguish between possibilities, but near instantaneous changes in enzyme activity in response to altered physical/chemical conditions (e.g. $\mathrm{pH}$ optima curves of Expts $3 b$ and $7 b$ ) are strong evidence in support of immediate changes in the activity of individual enzymes. Regardless of the underlying biological responses, area-specific enzyme activity, and thus 
overall rates of substrate hydrolysis and product generation, were altered by the experimental treatments.

In summary, DIN, photosynthesis, and LOC all displayed regulatory ability on periphytic LAMP activity. The regulatory role of photosynthesis indicated that LAMP activity is another periphytic process influenced by direct algal-bacterial metabolic coupling, and that increased $\mathrm{pH}$ induced by photosynthesis caused most of the stimulation of LAMP activity. Variable influences of regulatory factors among identical laboratory and field experiments and frequent interactive effects indicated that regulation of LAMP activity is a complex, temporally variable process. Diurnal patterns in LAMP activity were observed in natural periphyton communities.

Acknowledgements. This work was supported by a National Science Foundation Graduate Fellowship (S.N.F.) and grant DEB-9806782 from the National Science Foundation (R.G.W.). This manuscript benefited from the comments of several anonymous reviewers.

\section{LITERATURE CITED}

Ainsworth AM, Goulder R (2000a) Downstream change in leucine aminopeptidase activity and leucine assimilation by epilithic microbiota along the River Swale, northern England. Sci Total Environ 251/252:191-204

Ainsworth AM, Goulder R (2000b) Epilithic and planktonic leucine aminopeptidase activity and leucine assimilation along the River Tweed, Scottish Borders. Sci Total Environ 251/252:83-93

An S, Joyce SB (2001) Enhancement of coupled nitrifiactiondenitrification by benthic photosynthesis in shallow estuarine sediments. Limnol Oceanogr 46:62-74

Bebout BM, Paerl HW, Crocker KM, Prufert LE (1987) Diel interactions of oxygenic photosynthesis and $\mathrm{N}_{2}$ fixation (acetylene reduction) in a marine microbial mat community. Appl Environ Microbiol 53:2353-2362

Bebout BM, Fitzpatrick MW, Paerl HW (1993) Identification of the sources of energy for nitrogen fixation and physiological characterization of nitrogen-fixing members of a marine microbial mat community. Appl Environ Microbiol 59:1495-1503

Boetius A, Lochte K (1996a) Effect of organic enrichments on hydrolytic potential and growth of bacteria in deep-sea sediments. Mar Ecol Prog Ser 140:239-250

Boetius A, Lochte K (1996b) High proteolytic activities of deep-sea bacteria from oligotophic polar sediments. Arch Hydrobiol Spec Issues Advanc Limnol 48:269-276

Carlton RG, Wetzel RG (1988) Phosphorus flux from lake sediments: effect of epipelic algal oxygen production. Limnol Oceanogr 33:562-570

Christensen PB, Nielen LP, Soerensen J, Revsbech NP (1990) Denitrification in nitrate-rich systems: diurnal and seasonal variation related to benthic oxygen metabolism. Limnol Oceanogr 35:640-651

Chróst RJ (1991) Environmental control of the synthesis and activity of aquatic microbial ectoenzymes. In: Chróst RJ (ed) Microbial enzymes in aquatic environments. Springer-Verlag, New York, p 29-59

Chróst RJ (1993) Microbial enzymatic degradation and uti- lization of organic matter. In: Overbeck J, Chróst RJ (eds) Microbial ecology of Lake Plußsee. Springer-Verlag, New York, p 118-174

Chróst RJ, Rai H (1993) Ectoenzyme activity and bacterial secondary production in nutrient-impoverished and nutrient-enriched freshwater mesocosms. Microb Ecol 25: $131-150$

Collos Y, Descolas-Gros C, Mornet F (1996) Diel variations in dissolved organic nitrogen in a coastal pond: relationships with carbon and nitrogen metabolism. J Exp Mar Biol Ecol 202:177-189

Espeland EM, Wetzel RG (2001a) Complexation, stabilization, and UV photolysis of extracellular and surface-bound glucosidase and alkaline phosphatase: implications for biofilm microbiota. Microb Ecol 42:572-585

Espeland EM, Wetzel RG (2001b) Effects of photosynthesis on bacterial phosphatase production in biofilms. Microb Ecol 42:328-337

Espeland EM, Francoeur SN, Wetzel RG (2001) Influence of algal photosynthesis on biofilm bacterial production and associated glucosidase and xylosidase activities. Microb Ecol 42:524-530

Francoeur SN, Wetzel RG, Neely RK (2001) A new spatiallyexplicit method for detecting extracellular protease activity in biofilms. Appl Environ Microbiol 67:4329-4334

Halemejko GZ, Chróst RJ (1986) Enzymatic hydrolysis of proteinaceous particulate and dissolved material in an eutrophic lake. Arch Hydrobiol 107:1-21

Hessen DO, Henrikson A, Smelhus AM (1997) Seasonal fluctuations and diurnal oscillations in nitrate of a heathland brook. Water Res 31:1813-1817

Hoppe HG (1983) Significance of exoenzymatic activities in the ecology of brackish water: measurements by means of methylumbelliferyl-substrates. Mar Ecol Prog Ser 11: 299-308

Hoppe HG (1986) Relations between bacterial extracellular enzyme activities and heterotrophic substrate uptake in a brackish water environment. Actes Colloques IFREMER 3: 119-128

Hoppe HG, Giesenhagen HC, Gocke K (1998) Changing patterns of bacterial substrate decomposition in a eutrophication gradient. Aquat Microb Ecol 15:1-13

Johnson MD (1995) Ecosystem dynamics of protests and bacteria in a lotic freshwater wetland. PhD thesis, The University of Alabama, Tuscaloosa

Jones JI, Eaton JW, Hardwick K (2000) The influence of periphyton on boundary layer conditions: a $\mathrm{pH}$ microelectrode investigation. Aquat Bot 67:191-206

Jones SE, Lock MA (1993) Seasonal determination of extracellular hydrolytic activities in heterotrophic and mixed heterotrophic/autotrophic biofilms from two contrasting rivers. Hydrobiologia 257:1-16

Jørgensen BB, Revsbech NP, Cohen Y (1983) Photosynthesis and structure of benthic microbial mats: microelectrode and SEM studies of four cyanobacterial communities. Limnol Oceanogr 28:1075-1093

Kahn WE, Wetzel RG (1998) Effects of microscale water level fluctuations and altered ultraviolet radiation on periphytic microbiota. Microb Ecol 38:253-263

Keil RG, Kirchman DL (1999) Utilization of dissolved protein and amino acids in the northern Sargasso Sea. Aquat Microb Ecol 18:293-300

Kemp MJ, Dodds WK (2001) Centimeter-scale patterns in dissolved oxygen and nitrification rates in a prairie stream. J N Am Benthol Soc 20:347-357

Kroer N, Jorgensen NOG, Coffin RB (1994) Utilization of dissolved nitrogen by heterotrophic bacterioplankton: a 
comparison of three ecosystems. Appl Environ Microbiol 60:4116-4123

Law BA (1980) Transport and utilization of proteins by bacteria. In: Payne JW (ed) Microorganisms and nitrogen sources. John Wiley and Sons, New York, p 381-409

Mallet C, Debroas D (1999) Relations between organic matter and bacterial proteolytic activity in sediment surface layers of a eutrophic lake (Lake Aydat, Puy de Dôme, France). Arch Hydrobiol 145:39-56

Mallet C, Debroas D (2000) Regulation of aminopeptidase activity in the sediments of a eutrophic lake. Arch Hydrobiol 149:327-335

Manny BA, Wetzel RG (1973) Diurnal changes in dissolved organic and inorganic carbon and nitrogen in a hardwater stream. Freshw Biol 3:31-43

Martinez J, Azam F (1993) Aminopeptidase activity in marine chroococcoid cyanobacteria. Appl Environ Microbiol 59: 3701-3707

Matsuda Y, Koseki M, Shimadda T, Saito T (1995) Purification and characterization of a vegetative lytic enzyme responsible for liberation of daughter cells during the proliferation of Chlamydomonas reinhardtii. Plant Cell Physiol 36:681-689

Mayer LM (1989) Extracellular proteolyic enzyme activity in sediments of an intertidal mudflat. Limnol Oceanogr 34: 973-981

Montuelle B, Kestemont P, Chalamet A (1992) Kinetics of amino acid mineralization by a pond sediment bacterial community. Hydrobiologia 243/244:71-77

Moss B (1972) The influence of environmental factors on the distribution of freshwater algae: an experimental study. I. Introduction and the influence of calcium concentration. J Ecol 60:917-932

Münster U (1991) Extracellular enzyme activity in eutrophic and polyhumic lakes. In: Chróst RJ (ed) Microbial enzymes in aquatic environments. Springer-Verlag, New York, p 96-122

Münster U (1992) Microbial extracellular enzyme activities and biopolymer processing in two acid polyhumic lakes. Arch Hydrobiol Ergebn Limnol 37:21-32

Murray RE, Cooksey KE, Priscu JC (1986) Stimulation of bacterial DNA synthesis by algal exudates in attached algalbacterial consortia. Appl Environ Microbiol 52:1177-1182

Nausch M, Nausch G (2000) Stimulation of peptidase activity in nutrient gradients in the Baltic Sea. Soil Biol Biochem 32:1973-1983

Neely RK, Wetzel RG (1995) Simultaneous use of ${ }^{14} \mathrm{C}$ and ${ }^{3} \mathrm{H}$ to determine autotrophic production and bacterial protein production in periphyton. Microb Ecol 30:227-237

Nielsen LP, Christensen PB, Revsbech NP, Soerensen J (1990) Denitrification and oxygen respiration in biofilms studied with a microsensor for nitrous oxide and oxygen. Microb Ecol 19:63-72

Paerl HW, Fitzpatrick M, Bebout BM (1996) Seasonal nitrogen fixation dynamics in a marine microbial mat: potential roles of cyanobacteria and microheterotrophs. Limnol

Editorial responsibility: Karin Lochte,

Kiel, Germany
Oceanogr 41:419-427

Payne JW (1980) Transport and utilization of peptides by bacteria. In: Payne JW (ed) Microorganisms and nitrogen sources. John Wiley and Sons, New York, p 211-256

Rego JV, Billen G, Fontigny A, Somvile M (1985) Free and attached proteolytic activity in water environments. Mar Ecol Prog Ser 21:245-249

Revsbech NP, Jørgensen BB, Blackburn TH, Cohen Y (1983) Microelectrode studies of the photosynthesis and $\mathrm{O}_{2}, \mathrm{H}_{2} \mathrm{~S}$, and $\mathrm{pH}$ profiles of a microbial mat. Limnol Oceanogr 28: 1062-1074

Richardot M, Debroas D, Thouvenot A, Romagoux JC, Berthon JL, Devaux J (1999) Proteolytic and glycolytic activities in size-fractionated surface water samples from an oligotrophic reservoir in relation to plankton samples. Aquat Sci 61:279-292

Romani AM, Sabater S (2000) Effect of primary producers on the heterotrophic metabolism of a stream biofilm. Freshw Biol 41:729-736

Rosenstock B, Simon M (1993) Use of dissolved combined and free amino acids by planktonic bacteria in Lake Constance. Limnol Oceanogr 38:1521-1531

Rosenstock B, Simon M (2001) Sources and sinks of dissolved free amino acids and protein in a large and deep mesotrophic lake. Limnol Oceanogr 46:644-654

Sala MM, Karner M, Arin L, Marrasé C (2001) Measurement of ectoenzyme activities as an indication of inorganic nutrient imbalance in microbial communities. Aquat Microb Ecol 23:301-311

Sinsabaugh RL, Linkins AE (1988) Exoenzyme activity associated with lotic epilithon. Freshw Biol 20:249-261

Sinsabaugh RL, Findlay S, Franchini P, Fischer D (1997) Enzymatic analysis of riverine bacterioplankton production. Limnol Oceanogr 42:29-38

Stanley EH, Ward AK (1997) Inorganic nitrogen regimes in an Alabama wetland. J N Am Benthol Soc 16:820-832

Stepanauskas R, Edling H, Tranvik LJ (1999) Differential dissolved organic nitrogen availability and bacterial aminopeptidase activity in limnic and marine waters. Microb Ecol 38:264-272

Unanue M, Azúa I, Barcina I, Egea L, Iriberri J (1993) Size distribution of aminopeptidase activity and bacterial incorporation of dissolved substrates in three aquatic systems. FEMS Microbiol Ecol 102:175-183

Wetzel RG, Likens GE (2000) Limnological analyses, 3rd edn. Springer-Verlag, New York

Wetzel RG, Hatcher PPG, Bianchi TS (1995) Natural photolysis by ultraviolet irradiance of recalcitrant dissolved organic matter to simple substrates for rapid bacterial metabolism. Limnol Oceanogr 40:1369-1380

Woodruff SL, House WA, Callow ME, Leadbeater BSC (1999) The effects of biofilms on chemical processes in surficial sediments. Freshw Biol 41:73-89

Zar JH (1984) Biostatistical analysis, 2nd edn. Prentice-Hall, Engelwood Cliffs, NJ

Submitted: April 12, 2002; Accepted: December 18, 2002

Proofs received from author(s): March 11, 2003 